\title{
The Role of the Campaign Team as Brokers: The Case of the Minahasa Regent Election in 2018
}

\author{
Atler Septimus Ughude ${ }^{1}$, Panji Anugrah Permana ${ }^{2}$ \\ \{atler31@gmail.com ${ }^{1}$,panji.anugrah@gmail.com ${ }^{2}$ \} \\ Universitas Indonesia, Indonesia ${ }^{1}$ \\ Universitas Indonesia, Indonesia ${ }^{2}$
}

\begin{abstract}
The recruitment of a political machine to win elections is generally done by political parties and candidates, but in Indonesia, it has most often been done directly by candidates. However, a different scenario occurred in the Minahasa Regent election in 2018, where the Roring-Dondokambey campaign team was recruited and organized by a party. This study analyzes the campaign team's capacity and its role in the election. The paper argues that the campaign team consisted of people with strong capacities and appropriate clientelist strategies play an important role to win the candidates. This article draws on Zarazaga's theory of brokers' capacity as a political machine and Nichter's clientelist approach model, i.e., the campaign team recruited by the PDI-P had local knowledge, political reputations as elites, knowledge of the party's reputation, and the ability to maintain voter loyalty. Team members used these capacities to buy votes and reward loyalists in order to win the election.
\end{abstract}

Keywords: Campaign Team, PDI-P, Capacity, Clientelist, Brokerage.

\section{Introduction}

Scholars of clientelism generally believe that reciprocal relationships and the crucial position of brokerage institutions are paramount features of clientelist relationships. Stokes states that clientelist parties trade benefits for voters in return for their votes [1]. In line with Stokes, other researchers such as Gans-Morse, Mazzuca, and Nichter specify that the benefits offered in the clientelist relationship are food, building materials, mattresses, clothing, etc. Concerning the distribution of these goods, clientelist parties recruit political machines to ensure that voters who receive the benefits will vote for a certain party candidate. This is done because the party cannot influence the choices of others, especially by threatening to punish them for choosing another party [2].

Zarazaga (2014) explains that the current role of political machines has evolved to be more complex than employing clientelist strategies such as vote buying and mass mobilization. It now includes pre-electoral, election day, and post-electoral events. In the campaign phase, political machines take on various roles such as campaigning like party activists, which may involve putting up posters and organizing party meetings. On election day, they act as party voting officers. Then, in the post-election phase, they help their political party by assisting with the delivery of goods and public services [3].

In an electoral study in Northeastern Brazil, Nichter finds that farmers are the target of clientelist strategies by political machines. The political machine invites the farmers to drink 
alcohol and offers around 500 U.S. dollars if they agree to vote for certain candidates. Representatives then watch over the polls to ensure that the farmers follow through on the agreement. The practice of electoral clientelism in Brazil is often carried out by politicians who develop long-term relationships with the citizens through the provision of sustained selective benefits in return for political support. The citizens often rely on these relationships with politicians to fulfill their needs because the state has failed to offer certain provisions [4].

In the Indonesian context, political machines are known as campaign teams. Their existence came to the fore following the introduction of direct local elections in 2004, and they replaced the previous mechanism in which local heads of executives were elected by local parliaments. Since then, the competition among candidates for local executive offices (governors, regents, or mayors) has been much higher in comparison to the previous era. The candidates need votes from the electorates, and this situation creates the need for the candidates to establish their own campaign teams.

However, the establishment of a campaign team is not always similar across cases, in particular if we look at recruitment patterns. Some team members are recruited by the candidates following a structured nature, while others join through unstructured means. A structured campaign team usually consists of people who have strong personal capacity and are paid to mobilize voters. On the other hand, an unstructured campaign team frequently comprises family members or friends of the candidates who work for free [5].

In Indonesian election studies, several researchers have examined the role and composition of campaign teams, including their recruitment patterns. In 2017, in the Kendari mayoral election, one of the candidates, Adriatma Dwi Putra, was supported by his father, who was the incumbent mayor. His father helped recruit the campaign team, which consisted of a bureaucratic apparatus with people ranging from heads of offices (kepala dinas) to sub-district heads (camat) and village headmen (kepala desa), who were assigned to mobilize voters by giving them cash and pork barrel projects [6].

Another example is the recruitment of the campaign team in the 2013 Tanah Laut Regent election. One of the candidates, Bambang Alamsyah, utilized a political machine to win the election. His strategy was to reach out to people with strong religious social networks. Through his campaign team, he then engaged in vote buying through pork barrel projects and the provision of cash and goods to voters [7].

The patterns of recruitment of political machines or campaign teams differ between Latin America and Indonesia. In Latin America, political machines are recruited by political parties and candidates, while in Indonesia, they are recruited by candidates directly. However, the 2018 Minahasa Regent election demonstrated a different phenomenon, where political parties played a crucial role in the recruitment of political machines. This research explores this phenomenon with the aim of clarifying why it occurred and its role in the electoral competition.

\section{Conceptual Framework}

Zarazaga's analytical concept of brokers' capacity as a political machine is used to analyze the capacity of the Roring-Dondokambey campaign [3]. In addition, Nichter's clientelist approach model is used to scrutinize the role of the campaign team in the election.

\subsection{Brokers' capacity as a political machine}


Zarazaga (2014) elaborates brokers' capacity as a political machine in electoral competitions according to their four main capacities. First, brokers have sufficient knowledge and familiarity with their social surroundings, which are needed to carry out political activities. Brokers differ from ordinary people, who may lack political awareness concerning their social environment. Second, brokers frequently occupy important positions in their local communities. Prior to an election, they conduct non-clientelist activities to consolidate these positions. Third, brokers have the capacity to gather information and maintain awareness of their political party's reputation from the viewpoint of the electorate, which helps the political party provide resources and guarantee voters' loyalty. Fourth, brokers have the capacity to secure resources and a reputation among voters for being promises-keepers [3]. This theoretical explanation of brokers' capacities as a political machine applies to the capacity of the Roring-Dondokambey campaign team.

\subsection{Clientelist approach model}

The theory of brokers' capacity guides us to take a closer look at their strategies. Nichter (2010) divides clientelist strategies into five categories: vote buying, turnout buying, abstention buying, double persuasion, and rewarding loyalists. Vote buying is the giving of rewards to opposition supporters with the aim of winning their vote. Turnout buying is the provision of rewards to push voters to go to the polling station (for those who did not intend to vote). Abstention buying is the giving of rewards to voters for not voting. Double persuasion is a benefit given to electorates to encourage their political participation and influence their vote. Rewarding loyalists is the provision of special rewards to supporters, distributed by brokers [2].

This study focuses on vote buying and rewarding loyalists to analyze the role of the RoringDondokambey campaign team. These activities are chosen because they pertain to categories of voters who definitely plan to vote in the elections. Here, rewards refer to various objects and activities such as cash, goods (e.g., campaign shirts, hats, pins, calendars, etc.), and pork barrel projects (programs that include the construction of public facilities, education, and health). Vote buying is defined as the Roring-Dondokambey campaign team giving rewards to voters in the sub-districts known as Sarundajang-Runtu's base. These sub-districts include West Kawangkoan, North Kawangkoan, West Langowan, South Langowan, East Langowan, North Langowan, Tompaso, West Tompaso, West Tondano, South Tondano, and East Tondano. The Roring-Dondokambey campaign team bought votes in opponent sub-districts. Meanwhile, rewarding loyalists can be interpreted as the giving of rewards to voters in the PDI-P base subdistricts. These sub-districts include Tombulu, Tombariri, East Tombariri, Mandolang, and Pineleng.

\section{Research Method}

The research applies a qualitative method. Data in the form of text and images were collected from legal documents, academic literature, and media publications. In the light of the above theoretical framework, we analyze the data in the subsequent part of empirical findings. 


\section{Results}

\subsection{The 2018 Minahasa Regent election}

As the major supporting party of the Royke Octavian Roring-Robby Dondokambey ticket, the PDI-P had the right to recruit the campaign team. Before the campaign team was recruited, several national polls such as the Populi Center and the SMRC predicted a victory by Ivan Sarundajang and Careig Naichel Runtu from the Golkar Party. Based on a survey by Populi Center in February 2018, Sarundajang-Runtu had $50.7 \%$ of the popular support, while RoringDondokambey had only $42 \%$ [8]. A survey by the SMRC showed a similar result, with the electability of Sarundajang-Runtu above $50 \%$ of electoral support. Other local polls even predicted that Sarundajang-Runtu had about $60 \%$ of the popular support [9].

Furthermore, political observers in North Sulawesi speculated that Sarundajang-Runtu was stronger than Roring-Dondokambey due to their socio-political networks. As politicians, the former had more followers in comparison to the latter, who were career bureaucrats [10]. The position as incumbents also favored the Sarundajang-Runtu ticket. For example, as Table 1 data show, the mayoral elections in 2008 and 2013 were won by the incumbents.

Table 1. Regent and Deputy Regent of Minahasa Regency 2003-2018

\begin{tabular}{|c|l|c|c|}
\hline Number & \multicolumn{1}{|c|}{$\begin{array}{c}\text { Name of Elected Regent } \\
\text { and Deputy Regent }\end{array}$} & Period & Party \\
\hline 1 & $\begin{array}{l}\text { Stevanus Vreeke Runtu and } \\
\text { Rull Kuron }\end{array}$ & $2003-2008$ & Golkar Party \\
\hline 2 & $\begin{array}{l}\text { Stevanus Vreeke Runtu and } \\
\text { Jantje Wowiling Sajow }\end{array}$ & $2008-2013$ & Golkar Party \\
\hline 3 & $\begin{array}{l}\text { Jantje Wowiling Sajow and } \\
\text { Ivan Sarundajang }\end{array}$ & $2013-2018$ & PDI-P \\
\hline
\end{tabular}

Source: Various sources

After the recruitment of the campaign team, surveys showed that Roring-Dondokambey's electability increased and began to overtake that of Sarundajang-Runtu. Based on a survey by Populi Center in May 2018, Roring-Dondokambey's electability rose to $54.8 \%$, while Sarundajang-Runtu's dropped to $30.0 \%$ [8]. By June 2018, the electability of RoringDondokambey had increased to $64.8 \%$ [11]. This prediction was proven true on election day, June 27, 2018: Roring-Dondokambey won the election with 132,152 votes $(64.41 \%)$, while Sarundajang-Runtu obtained only 70,900 votes (35.59\%) [12].

Roring-Dondokambey won in 23 sub-districts and lost in two sub-districts by a slight margin. More importantly, they won the election in the stronghold region of the PDI-P (Tombulu, Tombariri, Tombariri Timur, Mandolang, and Pineleng). The two sub-districts in which they lost were Kawangkoan and North Tondano, which were known as SarundajangRuntu's base. Of note was that Roring-Dondokambey won in 11 of 13 sub-districts also considered part of Sarundajang-Runtu's base. The 11 sub-districts were Kawangkoan Barat, Kawangkoan Utara, Langowan Barat, Langowan Selatan, Langowan Timur, Langowan Utara, Tompaso, Tompaso Barat, West Tondano, South Tondano, and East Tondano. 


\subsection{Composition of the campaign team}

The Roring-Dondokambey campaign team can be divided into a formal and non-formal group. The formal campaign team was recruited and registered in the Local Election Commission (KPU). Its members were government officials and local political elites, party members, and entrepreneurs. On the other hand, the non-formal campaign team was not registered in the local election commission and consisted largely of representatives of community groups and regions in Minahasa district.

The majority of the campaign team were formal and informal elites of Minahasa, and this provided several advantages for the candidates. Most members of the formal campaign team held important positions in the Minahasa Regency or North Sulawesi Province [13]. The formal campaign team had elites in the government (such as the Governor and Deputy Governor of North Sulawesi Province, Mayor and Deputy Mayor of Manado City, North Minahasa Regency Regent, Deputy Regent of Southeast Minahasa Regency, and Minahasa Regent himself) and some in the legislature (several parliament members at the national, provincial, and regional levels, as well as members of the regional representative council/DPD-RI). The non-formal campaign team included pioneers in community leadership, such as Tou Sonder, Keraton and Langowan Raya. With such impressive backgrounds, the campaign team members brought strength of reputation, local knowledge, and access to the electorates.

In addition, the Roring-Dondokambey campaign team had the capacity to know the party's reputation and could guarantee voter loyalty. In accessing the electorates, the campaign team created several voluntary groups (including young volunteers) who actively engaged in consolidating electoral mobilization. These young volunteers included members of Barisan Steven Octavianus Kandouw (Basoka), whose members were spread throughout the subdistricts, villages, and even remote villages [14]. There were also Banteng Karu Kami volunteers and Lalambesik Merah volunteers, who were engaged in the District of Tompaso Raya [15]. In Tondano Raya, several volunteers mobilized electorates such as Bifi Merah R3D, The Rex, CNN, and Winawanua [16].

Furthermore, the campaign team members had a strong reputation with voters, as the majority held public offices. Their political positions helped provide political access to their own constituent base and larger communities in Minahasa. In addition, some volunteers such as Tou Sonder, Keraton, and Langowan Raya, were community leaders and former Hukum Tua (headmen, who were respected by local people).

\subsection{Clientelist strategy}

Roring-Dondokambey's victory was inseparable from the role the campaign team played in employing a clientelist strategy that included vote buying and rewarding loyalist.

\subsubsection{Vote buying}

This study follows Nichter's definition of vote buying, i.e., vote buying is the provision of rewards to opposition supporters with the aim of winning their vote. Based on data from various sources, one role of the campaign team was to participate in program campaigning. For example, in a campaign held in South Tondano, campaign team member Rendy Wulur offered several benefits if Roring-Dondokambey won. These benefits included the construction of shopping centers, international standard schools, and infrastructure improvements [17]. In a campaign in Langowan Raya, another member of the campaign team, Jantje Wowiling Sajow, promised that 
development in Minahasa would be performed quickly and easily because Dondokambey was the sibling of the Governor of North Sulawesi Province, Olly Dondokambey [18]. Jantje also promised to accelerate the development of a tourist attraction, Bukit Kasih, located in the Kawangkoan Barat District [19].

\subsubsection{Rewarding loyalists}

Referring back to Nichter's definition, rewarding loyalists consists of giving special rewards to supporters, distributed by brokers. Based on findings from various sources, the campaign team offered various programs for people in Tombulu, Tombariri, Tombariri Timur, Mandolang, and Pineleng sub-districts. In a campaign in Tombulu sub-district, Jantje said that Roring-Dondokambey would realize programs including the construction of a road from North Tombuluan to Minahasa [20].

Furthermore, based on the election violation data from the Election Supervisor Body (Bawaslu) of Minahasa, cash rewards were given during a Lotta Village birthday celebration, organized by the headman of Lotta Village in Pineleng District. Royke Roring's wife and her team attended and provided cash assistance worth Rp1,500,000 to the winner of a competition. According to the witnesses' report, the headman of Lotta showed his non-neutrality through activities such as putting the PDI-P banner up at his office, giving mourning money representing the local head of the PDI-P, and offering his house for use by the Roring-Dondokambey campaign [21].

\section{Conclusion}

The Roring-Dondokambey campaign team in the 2018 Minahasa Regent election stands out as an example of a political machine formed by a party, not just a candidate, in Indonesia. The team's composition and role were the keys to achieving victory for the PDI-P in the 2018 Minahasa Regent election. The campaign team comprised people with a mastery of local knowledge and good political reputations in Minahasa. They kept up to date on the party reputation and could guarantee voter loyalty. Moreover, they capitalized on their positions and reputations to carry out vote buying and reward loyalists in the form of giving cash and pork barrel projects to voters. Thus, through their capacity as a political machine and use of a clientelist approach, they were able to influence the election outcome.

\section{References}

[1] S. C. Stokes, "Perverse accountability: A formal model of machine politics with evidence from Argentina," Am. Polit. Sci. Rev., vol. 99, no. 3, pp. 315-325, 2005.

[2] J. Gans-Morse, S. Mazzuca, and S. Nichter, "Varieties of clientelism: Machine politics during elections," Am. J. Pol. Sci., vol. 58, no. 2, pp. 415-432, 2014.

[3] R. Zarazaga, "Brokers beyond clientelism: A new perspective through the Argentine case," Lat. Am. Polit. Soc., vol. 56, no. 3, pp. 23-45, 2014.

[4] S. C. Nichter, "Politics and poverty: Electoral clientelism in Latin America." UC Berkeley, 2010.

[5] M. Sukmajati and E. E. Aspinal, "Politik Uang di Indonesia," Polgov: Yogyakarta, 2014.

[6] R. A. Pratama, "Patronase dan Klientelisme pada Pilkada Serentak Kota Kendari Tahun 2017," J. Wacana Polit., vol. 2, no. 1, pp. 33-45, 2017. 
[7] E. Aspinall and M. U. As'ad, "The patronage patchwork: Village brokerage networks and the power of the state in an Indonesian election," Bijdr. tot taal-, land-en volkenkunde/Journal Humanit. Soc. Sci. Southeast Asia, vol. 171, no. 2-3, pp. 165-195, 2015.

[8] S. Pangemanan, "Tidak Terkejar 54,8\% RR-RD Unggul di Pilkada Minahasa," Manado Line, 2018. .

[9] Manado Post Online, "Survei Sebut Ivansa-CNR Bakal Menang Besar," Manado Post Online, 2018. .

[10] Manado Post Online, "Ivansa-CNR Disurvei," Manado Post Online, 2017. .

[11] JPPN, "Paslon dari PDIP ini Bakal Menang Telak Sulit Terkejar," JPPN, 2018.

[12] KPU Kabupaten Minahasa, "Hasil Rekapitulasi Perolehan Suara Pilkada Minahasa Tahun 2018," KPU Kabupaten Minahasa, 2018. .

[13] Tondano: KPU Kabupaten Minahasa, "Penggantian Nama Tim Kampanye dan Penghubung Pasangan Calon dalam Pemilihan Bupati dan Wakil Bupati Minahasa tahun 2018," Tondano: KPU Kabupaten Minahasa, 2018. .

[14] F. Assa, "Kandouw: Relawan BASOKA Hadir Untuk Menangkan R3D," Manado Line, 2018. .

[15] R. Sondakh, "Relawan Tompaso dan Tonsewer Perkuat Barisan R3D, JWS Optimis," Sulut Express, 2018.

[16] Indobrita, "Kaula Muda Tondano Komitmen Dukung dan Pilih R3D," Indobrita, 2018. .

[17] Berita Minahasa, "Kampanye Tondano Selatan, Pendukung Ivan-CNR Berbalik Mendukung RRRD," Berita Minahasa, 2018.

[18] Indobrita, "Kampanye di Langowan Raya, Banyak Pendukung Menangis Ingin Ketemu R3D," Indobrita, 2018.

[19] Aktual Sulut, "Kampanye Tahap II Bergulir, Nyatakan Sikap Bakal Menangkan RR-RD,” Aktual Sulut, 2018.

[20] Kabar Post, "Spektakuler, Kampanye RR-RD Dihadiri Ribuan Masyarakat Tombulu,” Kabar Post, 2018. .

[21] Tondano: Bawaslu Kabupaten Minahasa., "Laporan Penanganan Pelanggaran: Divisi Hukum dan Penindakan Pelanggaran (HPP) Pemilihan Bupati dan Wakil Bupati Kabupaten Minahasa Tahun 2018," Tondano: Bawaslu Kabupaten Minahasa., 2018. . 